Business collateral and personal commitments in SME lending Peer-reviewed author version

VOORDECKERS, Wim \& STEIJVERS, Tensie (2006) Business collateral and personal commitments in SME lending. In: Journal of Banking and Finance, 30(11). p. 3067-3086.

DOI: 10.1016/j.jbankfin.2006.05.003

Handle: http://hdl.handle.net/1942/1530 


\title{
Business collateral and personal commitments in SME lending.
}

\author{
Wim Voordeckers", Tensie Steijvers \\ Hasselt University, KIZOK Research Institute, Agoralaan - Building D, B-3590 \\ Diepenbeek, Belgium
}

\begin{abstract}
Using a database of SME credit approvals from a large Belgian bank, this paper extends the empirical evidence on the determinants of collateral by examining the determinants of business collateral simultaneously with the determinants of personal collateral/commitments. Our results suggest that firm and relationship characteristics seem to be more important determinants of collateral/commitment protection than loan and lender characteristics. Family firms are more likely to offer a higher degree of collateral/commitment protection while introducing competition between banks decreases this likelihood. The collateral requirement decreases in the length of the bank-borrower relationship. Furthermore, trade credit seems to have a signalling effect. The 'lazy banks hypothesis' was not supported. Our results suggest that beside risk arguments, also commercial arguments help explain the pledging of collateral. Using a continuation-ratio logit model, we discover several differences in the determinants of the collateralisation decision and the determinants of the type of collateral/commitments.
\end{abstract}

JEL classification: M13; G21; G30; G32; C35

Keywords: SME lending, business collateral, personal collateral, personal guarantees.

\footnotetext{
${ }^{*}$ Corresponding author. Tel.: +32-11-268613; Fax: +32-11-268700;

E-mail address: wim.voordeckers@uhasselt.be

Acknowledgements: This paper is based on chapter 6 of the doctoral dissertation of Tensie Steijvers. We would like to thank the other members of the dissertation committee Marc Deloof, Hans Degryse, Eddy Laveren, Arthur Limère and Roger Mercken for helpful comments. The authors would also like to thank Marc Aerts, David De Meza, Mateus Cesario and seminar participants at the EFMA Conference 2003 and the Belgian Financial Research Forum workshop 2003 for helpful suggestions and the Belgian bank for providing the database.
} 


\title{
Business collateral and personal commitments in
}

\author{
SME lending.
}

\begin{abstract}
Using a database of SME credit approvals from a large Belgian bank, this paper extends the empirical evidence on the determinants of collateral by examining the determinants of business collateral simultaneously with the determinants of personal collateral/commitments. Our results suggest that firm and relationship characteristics seem to be more important determinants of collateral/commitment protection than loan and lender characteristics. Family firms are more likely to offer a higher degree of collateral/commitment protection while introducing competition between banks decreases this likelihood. The collateral requirement decreases in the length of the bank-borrower relationship. Furthermore, trade credit seems to have a signalling effect. The 'lazy banks hypothesis' was not supported. Our results suggest that beside risk arguments, also commercial arguments help explain the pledging of collateral. Using a continuation-ratio logit model, we discover several differences in the determinants of the collateralisation decision and the determinants of the type of collateral/commitments.
\end{abstract}

JEL classification: M13; G21; G30; G32; C35

Keywords: SME lending, business collateral, personal collateral, personal guarantees.

\section{Introduction}

The use of collateral is a common feature of credit contracts between firms and lenders. The question why the use of collateral is so widespread has been the subject of several theoretical contributions. In general, the contractual relationship between borrowers and lenders may be hampered by the presence of asymmetric information, adverse selection and moral hazard, usually leading to credit rationing. As such, the risk of lending may be reduced by collateral. Collateral may play the role of a signalling device for borrower quality (e.g. Chan and Kanatas, 1985; Bester, 
1985; Besanko and Thakor, 1987a, 1987b; Boot et al., 1991), may lower the agency costs of debt by preventing the problem of asset substitution (Jensen and Meckling, 1976) and mitigate Myers' (1977) underinvestment problem (Stulz and Johnson, 1985). In general, when moral hazard risk shows up in the lending relationship, collateral may play a disciplinary role in the behaviour of the borrower. Consequently, stronger creditor protection from collateral would lead to better credit terms or even the approval of credit that otherwise would not be granted. According to Mann (1997a, 1997b), secured credit limits the firms' ability to obtain future loans from other lenders or reduces the risk of excessive future borrowing.

Recently, Manove et al. (2001) criticized the unrestricted reliance on collateral and argued that this might have a negative impact on credit-market efficiency. They argue that banks are in a good position to evaluate the future prospects of new investment projects. Collateral will weaken the bank's incentives to do so. Especially for small firms, banks would do little screening and rely excessively on collateral. From the point of view of banks, collateral and screening can be considered as substitutes.

Despite the considerable amount of effort that has been devoted in the theoretical literature to the role of collateral in business lending, only few theoretical studies (e.g. Chan and Kanatas, 1985; Mann, 1997b) make the explicit distinction between personal and business collateral. Chan and Kanatas (1985) postulate that business and personal collateral are very similar. Nevertheless, Mann (1997b) argues that personal collateral is more effective in limiting the borrower's risk preference incentives by enhancing the likelihood that the principal will feel any losses personally. 
The empirical literature (Leeth and Scott, 1989; Ang et al., 1995; Avery et al., 1998; Harhoff and Körting, 1998; Degryse and Van Cayseele, 2000; Hanley, 2002) concerning the determinants of collateral is rather scant, partly due to data limitations. While it is well documented that small and medium-sized firms rely primarily on financial intermediaries as lenders, especially commercial banks (Cole et al., 1996), only partial clues exist as to the role of personal wealth or business wealth in the contractual details of lending arrangements. To date, as far as we are aware off, only two empirical studies (Ang et al., 1995; Avery et al., 1998) examine the topic. Both studies found that personal commitments are an important component of SME lending. However, no efforts have been made to refine such results by distinguishing the factors related to both personal commitments ${ }^{1}$ and business collateral usage. Moreover, no European empirical evidence is available to date.

This paper contributes to the literature in two ways. First, using a recent database of a large Belgian bank, new empirical evidence on the determinants of both types of collateral protection is presented. Prior research only concentrated on the determinants of business collateral or the determinants of personal commitments separately. We extend this literature by examining the determinants of business collateral simultaneously with the determinants of personal collateral/commitments. Therefore, we differentiate between three degrees of collateral/commitment protection demanded by the bank. These three categories are considered as ordinal or ordered categories ranging from 'no protection' to 'highest protection': (1) unsecured debt, (2) secured debt with only business collateral and (3) secured debt with personal commitments (with or without business collateral). The theoretical rationale for considering these three categories as ordinal can be found in the information

\footnotetext{
${ }^{1}$ Personal commitments are defined as both personal collateral and guarantees that make owners
} 
asymmetry of the borrower-lender relationship. The 'implicit value' of personal commitments as a disciplining device that limits the borrower's risk preference incentives is higher than for business collateral (Mann, 1997b), especially under corporate organisational forms such as is the case for the firms in our database. The lender receives explicit claims on personal assets and/or future wealth of the borrower (Ang et al., 1995), which he cannot rely on in the case of business collateral. Moreover, the likelihood that the borrower will feel any losses personally is higher when granting personal collateral. Based on these three categories of collateral/commitment protection, we estimated two kind of econometric models. In order to test the determinants of collateral/commitment protection as a continuum, we tested an ordered probit model. Furthermore, we investigated the differences between the determinants of business collateral and personal commitments by a continuationratio logit model with two binary choice models: (1) the choice with or without collateral/commitments and (2) the choice between business collateral or personal commitments, given that the bank has already decided to ask for some kind of collateral.

Second, the database contains specific data that allowed us to examine determinants that were not included in previous empirical studies such as the signalling role of trade credit (Biais and Gollier, 1997), the family factor and the 'lazy’ banks hypothesis (Manove et al., 2001).

Our results suggest that firm and relationship characteristics seem to be more important determinants than loan and lender characteristics. Furthermore, we find that beside risk arguments, also commercial arguments help explain the pledging of collateral. Using a continuation-ratio logit model, we discover several differences in 
determinants of the collateralisation decision and the determinants of the type of collateral/commitments.

The organization of the paper is as follows. Section 2 discusses the determinants of business collateral and personal commitments and develops the hypotheses. Section 3 explains the data set, the variables and the method. The empirical results are analysed in section 4 . Section 5 concludes the paper.

\section{The determinants of business collateral and personal commitments.}

\subsection{Firm characteristics}

A first firm characteristic that could have an influence on the use of personal commitments is the difference between family and non-family firms. Agency models predict that agency costs emerge with fractional ownership, a situation less frequent found in family firms. Furthermore, self-interest by family agents is tempered by kinship and altruism (Schulze et al., 2003). Family members, having a non-diversified portfolio of investment, are motivated and mainly concerned with the long-term survival of the firm (Ang, 1992). This induces a reduction in firm risk and volatility of cash flow in order to prevent default (Diamond, 1989; Bopaiah, 1998). Consequently, the interests of creditors (e.g. banks) are aligned with those of the shareholders. However, altruism also may have a drawback (Schulze et al., 2003), causing higher agency costs such as 'free riding' by family members (Bruce and Waldman, 1990), entrenchment of ineffective managers (Morck et al., 1988) or predatory managers (Morck and Yeung, 2003). Schulze et al. (2003) suggest that parents' altruism will lead them to be generous to their children even when these children free ride and lack the competence or intention to sustain the wealth creation potential of the firm. 
Linking this argument to the credit acquisition process, we expect that banks will be more cautious (higher collateral requirements) when dealing with family firms.

Furthermore, from the point of view of the firm, personal commitments could bring about potential agency problems between individual partners in SMEs, due to unequal risk sharing and free-riding among the partners. When some or all partners pledge personal collateral or guarantees, the actions of one partner can place the wealth and personal assets of all other partners at risk (Ang et al., 1995). Although this problem may be prevalent in both non-family and family firms, it is expected that because of stronger social bonds in the latter, family firms are less opposed to personal commitments than non-family firms.

H1: Family firms are expected to have a higher degree of collateral/commitment protection than non-family firms.

Trade credit could be used as a signalling instrument, mitigating the adverse selection problem. Biais and Gollier (1997) show in their model that trade credit can play an important role in the credit decision process of banks when suppliers have private information about their customers. Providing trade credit is a credible way for suppliers to convey their private information about the firm to the bank. This signalling effect would especially be prevalent when the bank is dealing with an affiliate company, receiving trade credit via the internal capital market. Internal capital markets are a major channel of capital allocation in modern industrial economies. These internal capital markets would be more efficient than external capital markets. They have an information advantage over banks and incur lower transaction costs when supplying finance. Within a group structure, it can be expected 
that the scarce financial resources they possess, are allocated optimally at group level (Stein, 1997). Gertner et al. (1994) also state that a firm which acquires intragroup financial resources, will be more subject to monitoring. The mother company possesses eventually the assets or the majority of the assets of each firm of the group and thus has the residual control over the assets causing a surplus for the mother company when monitoring the firms of the group. Since the financial institution knows that each group firm is heavily internally monitored, the financial institutions will have more trust in those firms. This might also reduce the liquidity constraints for firms within a conglomerate (Lamont 1997, Scharfstein and Stein, 2000), which was empirically confirmed by Shin and Stulz (1998) and Deloof (1998). Thus, when the signalling effect of trade credit is strong enough, the risk of lending decreases and the likelihood that firms have to offer collateral/commitment protection is reduced. On the other hand, the model developed by Wilner (2000) predicts that firms preferring trade credit are the less financially stable firms since renegotiation concessions are more likely. This would imply a negative signalling effect of the use of trade credit. This negative effect would be minor when trade credit is obtained within a group since Stein (1997) argues that the financial resources of a group, including trade credit, would only be given to the 'winners' among the affiliate firms. Moreover, the desire for an external supplier to maintain an enduring product market relationship and thus from a commercial point of view, renegotiate with the client in case of financial distress (Wilner 2000), is not applicable to supplier-client relationships if they both belong to the same group. 
H2: The use of trade credit is negatively related to the degree of collateral/commitment protection. This effect is predominantly expected in affiliate firms.

\subsection{Relationship characteristics}

Relationship banking stresses the fact that banks can improve their revenues by maximising the profitability of the actual relationship with the firm throughout time. So far, research on relationship lending mainly concerns the effect of a strong relationship on the interest rate and credit acquisition. Links between relationship strength and collateral have not received much attention in literature (Coco, 2000).

A relationship can be defined in numerous ways. The most common measure is the duration of the relationship with the bank (Petersen and Rajan, 1994, 1995; Berger and Udell, 1995; Angelini et al., 1998; Degryse and Van Cayseele, 2000; Ongena and Smith, 2001). Previous scant empirical research focusing on the link with collateral has stressed this duration of the relationship and has discovered that firms with a longer relationship with their bank incur a lower incidence of collateral (Berger and Udell, 1995; Harhoff and Körting, 1998), as predicted by the model of Boot and Thakor (1994). The capacities and the character of the entrepreneur become obvious as the relationship continues. Also the timely repayment of acquired loans contributes to the reliability of the firm. As time expires, the entrepreneur builds up a good reputation and the moral hazard problem will diminish (Diamond, 1989). Because a good reputation is considered a valuable asset, the firm will prefer a low-risk project above a high-risk project, reducing the probability of repayment difficulties and keeping the value of the reputation asset intact. The statement that the incidence of collateral is lower as the relationship matures, is also consistent with banks producing 
private information about the borrower quality as mentioned in the financial intermediation literature (Diamond, 1991; Ramakrishnan and Thakor, 1984).

H3: The duration of the relationship is negatively related to the degree of collateral/commitment protection.

An alternative measure for the strength of the relationship used in previous empirical research is the exclusivity of the relationship (Petersen and Rajan, 1994; Ferri and Messori, 2000; Degryse and Van Cayseele, 2000; Berger et al., 2001; Ongena and Smith, 2001). If a financial institution operates as the main banker for a firm, the firm mostly communicates with this particular bank. A bank is considered as the main banker if the relationship has a certain depth by means of purchasing other bank products or services. Through continuous interaction between bank and SME (concerning several bank products), the information asymmetry diminishes. Obviously, this intense communication between both parties creates a mutual trust and reduces the banks' risk involved in granting credit.

H4: The exclusivity of the bank-borrower relationship is negatively related to the degree of collateral/commitment protection.

Additionally, the number of banks a firm negotiates with before agreeing to a certain credit, may influence the relationship bank-SME. Working with just one bank creates the risk for the SME that this certain bank will abuse the power it has. The relationship between bank and SME creates internal information for the bank. This particular banker of the SME than has an information monopoly compared to other 
banks and may build up certain market power. This market power can be used in a negative way vis-à-vis the SME (Greenbaum et al., 1989; Sharpe, 1990; Rajan, 1992), for example by asking above-market rates ('ex post rent extraction') or a higher degree of protection by means of collateral or commitments. Changing banks becomes difficult for the SME since revealing its qualities in a credible way to another bank may take a lot of effort. Thus, the firm becomes 'locked in' in the relationship with the bank. In order to avoid the building up of market power by this one bank, the firm may choose to work with more banks. Multi-banking or negotiating and working with different banks, may reduce the motives of the bank to monitor the behavior of the debtor or collateral requirements (Rajan and Winton, 1995). Rajan and Winton (1995) argue that this result is consistent with the proposition that banks are not inclined to ask for collateral or commitments if this implies that the result of their screening activity is implicitly available to competing banks.

Furthermore, Jiménez and Saurina (2004) argue that, if a firm obtains debt finance from different banks, this increases the motivation at each bank to put a lot of effort in screening the firm before supplying debt finance. This is due to the relatively low information rents. The bank has no information monopoly and the information gathered by the bank is not private but also known by the other banks supplying debt finance. In the future, it is not possible for any bank to exploit an information monopoly by asking above-market interest rates (Greenbaum et al., 1989; Sharpe, 1990; Rajan, 1992; Petersen and Rajan, 1995). Consequently, the bank will only supply debt finance if the probability of default is very limited. Thus, offering protection to the bank by means of collateral or commitments is no longer necessary. 
H5: The use of competitive forces between banks during the credit request process is negatively related to the degree of collateral/commitment protection.

\subsection{Loan Characteristics}

The time to maturity or loan duration has an impact on the incidence of secured debt: long-term bank debt would be more often secured due to several reasons. First of all, long-term loans require a long-term judgement of the creditor on the creditworthiness of the debtor. A company that is creditworthy at the moment of a credit decision cannot assure that it will remain creditworthy in the future. The chance of occurrence of an adverse event becomes larger when the duration of the loan is enlarged. In this case, collateral has the power to decrease the ex ante loan assessment of risk. The pledging of collateral is an effective mechanism for the creditor to ascertain himself of a certain value in the future: a company may not retain its value on a longer term but collateral does most likely retain its value (Mann, 1997a).

Second, the problem of asset substitution is particularly present when providing long-term debt (Jackson and Kronman, 1979). The term of the loan gives the debtor enough opportunities to alter the projects in subtle ways or even switch from low-risk to high-risk projects. As loan duration falls, the reputation effect becomes much more important.

Third, for firms, which have acquired short-term debt and would actually engage in asset substitution, the wealth transfer would be relatively small compared to the reputation cost (higher future interest rates). Moreover, the speed required to substitute assets would raise costs for the debtor. Consequently, short-term loans will rely less on collateral provision (Leeth and Scott, 1989). In contrast, Stulz and Johnson (1985) argue the opposite. They assert that the value of collateral is a 
decreasing function of time to maturity. Consistent with the majority of the theoretical literature and the empirical research by Leeth and Scott (1989), Boot et al. (1991), Harhoff and Körting (1998) and Degryse and Van Cayseele (2000) we postulate the next hypothesis:

H6: The time to maturity of a loan is positively related to the degree of collateral/commitment protection.

From both a theoretical and empirical point of view, loan size would have a positive impact on the provision of collateral by a firm. The advantages of loans backed by collateral (e.g. preventing asset substitution, claim dilution, reducing foreclosure costs), have to be more extensive than the costs that are mainly fixed. For small loans, these benefits cited may not cover the fixed costs including monitoring costs, costs for asset appraisals and administrative expenses. Given these arguments, Jackson and Kronman (1979) conclude that larger loans should be more frequently secured. Loan size is also linked to the probability of default, since a firm that receives more debt attains a higher leverage level and so increases the risk of nonpayment (Leeth and Scott, 1989; Avery et al., 1998). Empirically, there is no consistency in the relationship between loan size and collateral or commitment protection. The results of studies of Harhoff and Körting (1998), Elsas and Krahnen (2000) and Degryse and Van Cayseele (2000) suggest that loans of a larger size are more often secured. The results in Boot et al. (1991) suggest the opposite. Following the majority of the empirical literature, we postulate:

H7: The size of a loan is positively related to the degree of collateral/commitment protection. 


\subsection{Lender Characteristics}

The screening effort - the time and effort a bank invests in screening the firm demanding for bank debt - could have an influence on the pledging of collateral. In case of SME lending, banks usually have superior expertise in judging the different aspects of project quality in comparison to the often-unrealistic optimistic entrepreneur (De Meza and Southey, 1996). Although the disciplining role of collateral to prevent moral hazard by borrowers is well described in literature, collateral also has a potential drawback. Manove et al. (2001) prove that collateral protection may induce banks to be 'lazy' and reduces their screening efforts below socially efficient screening levels. Especially for SMEs, it seems that banks do little screening and particularly rely on collateral or commitments demanded. Hence, collateral and screening could be considered as substitutes.

H8: The amount of screening efforts of the bank is negatively related to the degree of collateral/commitment protection.

\section{Data, variables and method}

\subsection{The data set}

This research project utilizes a database of credit file data of two large business centres of an important Belgian ${ }^{2}$ bank. The activities of this bank are divided

\footnotetext{
${ }^{2}$ Our database differs in several aspects from the database of Degryse and Van Cayseele (2000) who study collateral in the same Belgian context. First, while Degryse and Van Cayseele concentrate on single-person businesses and small firms (less than 10 employees and turnover of less than 7 million U.S. dollar), we concentrate on medium-sized firms (according to their criteria). The average number of employees in our sample is 40 (Item only available for 210 cases in the sample). Secondly, the time frame is different. Our database covers the period 2000-2003 while the database of Degryse and Van Cayseele (2000) covers the period 1995-1997.
} 
in three business lines ${ }^{3}$ : (1) retail banking, which is mainly oriented towards single person businesses (sole proprietorships) and small firms, (2) business centres, which cover lending to small and medium-sized firms and (3) corporate banking, which is oriented towards large and multinational firms. The bank has in almost every postal zone a retail branch but only a small number of business centre branches in one geographical region/province ${ }^{4}$. Our data comes from two such business centre branches (the second business line) covering almost half of the bank's credit portfolio of the geographical region/province ${ }^{5}$ they are operating in. The database contains a random selection of 248 credit files from the period January 2000 until February 2003. This is almost $20 \%$ of the total number of credit files ${ }^{6}$ approved during this period for these two business centres together. After removing cases with missing values and outliers, we ended up with a final sample of 234 cases. The majority of the cases are from 2001 (29.91\%) and 2002 (58.12\%). No starting firms were included in the database as the youngest firm in the sample has an age of already one year. Several firms in this business segment of the bank are part of a business group of firms. Therefore, our sample contains $14 \%$ credit files from affiliate firms. The database includes the data needed concerning firm characteristics, relationship characteristics, loan characteristics and lender characteristics.

\footnotetext{
${ }^{3}$ The division in these three business lines is based on a specific internal turnover criterion of the bank which we are not allowed to report because of reasons of confidentiality. The definition of small and medium-sized firms in this paper is based on this turnover criterion of the bank. Not all cases in the credit portfolio perfectly match the business centres' size criterion. Some smaller firms are included: e.g. affiliate firms as the mother firm is also included in the credit portfolio of the business centre.

${ }^{4}$ For more information about the bank landscape in Belgium and the geographical situation, see Degryse and Ongena (2005).

5 Regional biases in credit policy between geographical regions are not expected. Formalised interviews with the account managers revealed that the bank has one general credit policy. Account managers of the bank are allowed to decide themselves about a credit request below a certain amount threshold. However, the final approval decision for the majority of credit requests of business centres of this bank surpasses this threshold and is taken on a central level in the bank. Therefore, the sample although it is rather small - may be considered as representative for the credit policy of this bank.
} 


\subsection{Variables}

The dependent variable is treated as an ordered variable with three ordinal outcomes: (1) credit requests approved without any collateral (29 cases), (2) credit requests approved with only business collateral (134 cases), (3) credit requests approved with personal commitments ${ }^{7}$ (71 cases). The theoretical rationale for this classification can be found in the asymmetry of the borrower-lender relationship. The 'implicit value' of personal commitments as a disciplining device that limits the borrower's risk preference incentives surpasses that of business collateral (Mann, 1997b). This especially applies under corporate organisational forms which is the case for the firms in our database. The lender receives explicit claims on personal assets and/or future wealth of the borrower (Ang et al., 1995), which cannot be relied upon in the case of business collateral. Moreover, the likelihood that the borrower will feel any losses personally is higher when granting personal collateral. This justifies the way we define the third category and the ordinal character of the dependent variable.

Firm characteristics include the family versus non-family firm classification and trade credit. The distinction between family and non-family firms (H1) is measured by a dummy variable (FAMILY). A family firm is defined as a company in which the family has the majority of the shares. The influence of trade credit on collateral/commitment protection (H2) is tested with the proxy accounts payable scaled by total assets (TRADECR).

In order to test the influence of relationship characteristics on collateral/commitment protection, the natural logarithm of the number of years of the lending relationship $(H 3)$ is included as a first variable $(\ln (1+\mathrm{RELAT}))$. Furthermore,

\footnotetext{
${ }^{6}$ These credit files include bank loans as well as other financing solutions e.g. leasing and factoring. These other financing solutions are not included in our sample.
} 
we include in the model the number of competing banks for the same credit request (COMPETITION) $(\text { H5 })^{8}$ and a dummy variable (MAIN_BANK) in order to differentiate between the 'main bank' and other banks ${ }^{9}$ (H4).

Loan characteristics variables include the time to maturity of the loan ${ }^{10}$ in months (MATURITY) (H6) and the size of the loan as the natural log of the loan amount in Euro (H7). The lender characteristics include the number of days needed by the bank to judge the credit request (JUDGE_TIME) in order to test the 'lazy' banks hypothesis (H8).

In this study, we include four control variables: firm size (Ln of total assets), firm age, mother-daughter position and the year of credit approval. Firm age is measured by the age of the firm in months. The position in a group of companies (mother or affiliate company) can influence the credit decision. Therefore we included a dummy variable ( 1 for mother/independent company, 0 for affiliated companies). The year of approval is treated as a set of categorical dummy variables consisting of the four years $(2000,2001,2002,2003)$ in which the loan requests have been approved. Summary statistics and frequency tables of the independent variables in the model are reported in tables 1 and 2.

\footnotetext{
${ }^{7}$ The latter category includes loans with only personal commitments (only 4 cases) as well as loans with business collateral and personal commitments (67 cases). As soon as personal commitments are given, the case is classified in the third category.

${ }^{8}$ This number of competing banks is ex ante asked for by the account manager (before the credit is approved). The account manager assumes that the client is not withholding any information and states thruthfully the number of competing banks. The banker will verify this number of competing banks $e x$ post, after credit approval, at a central agency that collects the data on all loans granted in Belgium. In nearly all cases, there is no discrepancy found between the number of banks declared ex ante and verified ex post.

${ }^{9}$ This variable was coded by the account managers of the bank: 1 for main bank, 0 otherwise.

${ }^{10}$ The database contains loans with maturity and lines of credit that have no specified maturity. These lines of credit are coded " 0 " in the database by the bank. These zero values have in fact no meaning. To capture the difference between lines of credit and other loans, we introduced a dummy variable in the
} 
$* * * * * * * * * * *$ INSERT TABLE $2 \mathrm{HERE}$

\subsection{Method}

The dependent variable in our model is considered as ordinal as previously argued. Therefore, the relationship between the degree of collateral/commitment protection required by a bank and a group of independent variables is first estimated as an ordered probit model (Maddala, 1987). The problem with this approach is that we cannot investigate whether the determinants of the choice of asking collateral or not differs from the determinants of the choice of type of collateral (business or personal), once the decision to ask collateral is made. To solve this problem, we estimate a second regression with a continuation-ratio logit model (Agresti, 2002). A continuation-ratio logit model is useful when a sequential mechanism determines the response outcome such as in our model. We fitted the continuation-ratio logit model by estimating two binary logit models: the first estimates the choice between collateral or no collateral, the second estimates the choice between business collateral and personal commitments, given that the bank has already decided to ask for some kind of collateral.

\section{Empirical results}

\subsection{Discussion}

In table 3 and table 4 , the regression results of the ordered probit and continuation-ratio logit models are presented. The $\chi^{2}$ value is indicative of a strong overall significance of the econometric models. The pseudo- $\mathrm{R}^{2}$ in the continuationratio logit models are much higher for the collateralisation decision than for the type of collateral decision. This suggests that our model better explains the collateralisation 
decision than the type of collateral decision. Furthermore, a first investigation of the significant coefficients reveals that both decisions are partly driven by different determinants.

********** INSERT TABLE 3 HERE

$* * * * * * * * * *$ INSERT TABLE 4 HERE

The positive coefficient on the dummy variable 'FAMILY' in table 3 and negative coefficients in table 4 suggest, that being a family firm ${ }^{11}$ increases the likelihood that the firm has to offer more collateral/commitment protection to the bank in order to acquire a loan. This supports H1. The higher agency costs of altruism and the resulting higher risk profile of family firms are translated in a higher degree of collateral/commitment protection required by the bank.

The regression results of the ordered probit model (table 3) suggest that trade credit acts as a signalling device as predicted by the model of Biais and Gollier (1997). The negative coefficient on 'TRADECR' (table 3) indicates that firms receiving more trade credit are more likely to offer less protection to the bank by pledging any kind of collateral/commitment. In order to test the second part of $\mathrm{H} 2$, we included interaction dummies between MOTHDAU and TRADECR. The regression results (specification (3) in table 3) show that for both groups of firms, trade credit is negatively related to the degree of collateralisation. The coefficient for affiliated

recoding the variable MATURITY as " 0 becomes 1 " and "ELSE $=0$ ".

${ }^{11}$ Being a family firm may be considered as an interaction variable of several underlying variables including size. The family firms in our sample seem to be significantly smaller than non-family firms. Therefore, we include a proxy for size in the model as a control variable. We estimated also a model with interaction variables between size and family firms instead of size. The regression results (not reported) for family firms do not change. 
companies is higher ${ }^{12}(-2.954)$ than for mother companies (-1.423), giving weak support to the second part of $\mathrm{H} 2$.

The analysis of specification (1) and (2) in table 4 scrutinizes the relationship between collateralisation and trade credit. In the logit model concerning the choice between asking collateral or not, the coefficient of TRADECR is found to be not significantly different from zero. Although we find a negative effect on collateralisation, the signalling effect of trade credit is negligible in this decision. In the logit model concerning the choice of type of collateral/commitments, we find a strong negative significant relationship as expected. These results suggest that SMEs using more trade credit have a lower likelihood of pledging personal collateral/commitments ${ }^{13}$.

In general, relationship characteristics also appear to be related to the use of collateral/commitments. A very important element seems to be the exclusivity of the relationship (H4). Contrary to what was expected, if a financial institution operates as 'main bank' for a firm, this firm is more likely to pledge business collateral or even use personal commitments in order to acquire a loan (table 3). Nevertheless, these results are in line with Degryse and Van Cayseele (2000). Table 4 provides further evidence on this relationship. In the binary logit model of the collateralisation decision, the effect appears to be positive significant. In the other choice model concerning the type of collateral, no significant effect was found. Because Degryse and Van Cayseele (2000) do not provide a clear-cut explanation for this unexpected result in a Belgian context, we scrutinized this effect by discussing this result with the

\footnotetext{
${ }^{12}$ Statistically significant different on the $10 \%$ level.

${ }^{13}$ The specification (3) in table 3 could not be meaningfully tested in a continuation-ratio logit model because a very limited number of affiliated companies would be included in the type of collateral decision regression. However, in the collateralisation decision regression of this model, both coefficients are not statistical significant, but again, the coefficient of affiliated firms is larger than this of mother companies.
} 
account managers of the bank. From these discussions, we concluded that this result could be interpreted as the bank exploiting its power over the firm when being the main bank. This explanation is not new. Mann (1997b) already found in a U.S. context that the main reason for banks to take collateral is that secured credit limits the firms' ability to obtain future loans from other lenders and reduces the risk of excessive future borrowing. From our interviews, we learned that especially the 'commercial reason' to keep competing banks away from the client in the future seems to apply here. By asking collateral protection - even if it is not necessary banks try to build up a 'quasi-monopoly' position for each individual client. The main bank could take more collateral than necessary being a barrier-to-entry for other banks. The fact that we find a significant effect in the collateralisation regression and not in the type of collateral regression (table 4) is in support of this explanation. Not the type of collateral or commitments but the decision to take a certain amount of collateral matters when building up a quasi-monopoly position with regard to the client.

When we consider the length of the relationship (H3), we only find in one regression function (the collateralisation decision in model (2) of table 4) a weak statistical significant effect, giving some support for H3. Consistent with the findings of Degryse and Van Cayseele (2000), this result indicates that the probability of collateral requirements is slightly decreasing with the length of the bank-borrower relationship. Given the rather weak statistical significant effect and the inconsistency of this effect over the different models, the results do not fully confirm the "prospects based lending view' in Belgium which is based on the banks trust on the future condition of the firm and accordingly does not require a firm to pledge any kind of collateral (Binks and Ennew, 1997). Berger and Udell (2002) also argue that 
'prospects based lending' requires an organisational structure with less hierarchy and thus a simplified control and monitoring process. We can question whether this is the case at the moment in Belgium where financial institutions are increasingly growing in size and become more complicated, due to the consolidation process. Our results are consistent with Mayer (1988) who hypothesizes that firms can share risks with their bank throughout time and thus reduce the necessity of collateral provision, by means of a long-term relationship. However, this risk sharing is only possible when the flexibility of the borrowing firms to switch banks is limited. The banking sector in Belgium is characterized by a high degree of competition. Consequently, switching banks is ceteris paribus relatively easy for borrowing firms. This flexibility to switch banks prevents risk sharing between both parties throughout time. Subsequently, the length of the relationship cannot always be a substitute for collateral provision, which is consistent with the weak significance of the length of the bank-borrower relationship in our models as well as those of Degryse and Van Cayseele (2000).

Introducing more competition between banks has the hypothesized (H5) influence on collateral pledging. The results suggest that, if a company introduces a credit request with more banks, it diminishes the likelihood of granting any kind of collateral. When we divide this variable into three categorical dummy variables (specification (2) in tables 3 and 4), we find that this effect starts to work when at least three banks are competing for the same loan granted to a firm. The continuationratio logit models suggest that this effect is especially significant in the choice model of the collateralisation decision. Our results are not in line with those found in the empirical studies of Harhoff and Körting (1998) and Berger and Udell (1995) whose results indicate that introducing more banks in the credit acquisition process augments the probability of granting collateral. 
Loan characteristics show mixed results. From table 3, we see that loan size $(\ln ($ AMOUNT $))$ does not appear to have significant effects on the pledging of collateral/commitments. Only lines of credit and loans with a longer time to maturity are more likely to have a higher degree of collateral/commitment protection than other loans although the effect is only statistically significant at the $10 \%$ level. Table 4 provides some additional information. A higher loan amount is related with a lower likelihood of personal commitments and a higher likelihood of business collateral. This effect seems logical as larger loan amounts usually concern the financing of fixed assets. Fixed assets often have a high collateral value that makes personal commitments redundant. Lines of credit $(\mathrm{L} / \mathrm{C})$ and loans with a longer time to maturity are more likely to be collateralised. Nevertheless, they do not seem to be related to the type of collateral/commitments. Furthermore, no significant effects were found for the proxy of screening efforts (JUDGE_TIME). This means that the provocative proposition by Manove et al (2001) that banks would be lazy, in a sense that they ask more collateral as substitute for their screening efforts, is not supported by our results.

Examining the control variables, firm size $(\ln (\mathrm{TA}))$ and firm age $(\ln (\mathrm{AGE}))$, reveals that these are significant determinants of both the collateralisation and type of collateral/commitment decision (table 4). Larger firms are more likely to offer a higher degree of collateral/commitment protection to the bank. Although this result is not in line with expectations (Leeth and Scott, 1989), it can be explained by the kind of proxy we use. It is likely that this proxy (total assets) measures potential collateral value of the firm rather than size. Hence, interpreting the results might lead us to say that it is more likely that the bank will ask for collateral. Firm age seems to have a significant effect in both models. Loans of older firms are more likely to be 
collateralised. This result is also unexpected but not uncommon. A possible explanation is that older firms have a proven track record in which more information is revealed about the assets which are available as collateral. Moreover, older firms with an established track record are often more interesting for the bank from a commercial point of view. As previously argued, taking collateral is one way to hold on to an interesting client. In the type of collateral decision model (table 4), we see that older firms are - as expected - less likely to give personal commitments.

\subsection{Robustness}

During the credit approval process, bankers simultaneously decide about the loan characteristics. Because we included several loan characteristics as explanatory variables such as loan size and time to maturity, there is a probability that our results are biased by an endogeneity problem. In order to scrutinize this potential bias, we calculated the Smith-Blundell test for exogeneity (Smith and Blundell, 1986) for the two binary choice models from the continuation-ratio logit model with loan size and time to maturity as suspected endogenous variables. Although the test is specified for probit models, the strong analogy between probit and logit models makes the results applicable for the logit models in our study. The test statistic for the Smith-Blundell test of exogeneity (Chi-squared distributed, $\mathrm{df}=2)$ is $5.208(\mathrm{p}=0.074)$ for the collateralisation decision model and $1.247 \quad(\mathrm{p}=0.536)$ for the type of collateral/commitment model. We cannot reject the null hypothesis (on a 5\% significance level) that the models are appropriately specified with all explanatory variables as exogenous. Moreover, our regression results do not change when we reestimate all our models without the variables MATURITY and $\ln ($ AMOUNT). This suggests that our results are not expected to suffer from an endogeneity bias. 
Furthermore, we also tested two additional models (results not reported), one with the debt ratio (debt/total assets) and another with the asset specificity of the firm (total assets/employees) as added control variables. Both models show similar results. The debt ratio is not significant, asset specificity has a positive statistical significant relationship with the pledging of collateral such as expected.

\section{Conclusion}

The determinants of collateral have intrigued scholars for decades. Although in reality many SMEs have to pledge personal collateral/commitments, there is barely empirical evidence available about the determinants of these personal collateral/commitments. As far as our knowledge, we are the first that empirically investigate the determinants of personal collateral/commitments simultaneously with the determinants of business collateral for SMEs in a bank-oriented economy. Moreover, we provide empirical evidence about the differences in determinants of the collateralisation choice and the type of collateral decision.

Our results suggest that firm and relationship characteristics seem to be more important determinants of collateral/commitment protection than loan and lender characteristics. The results indicate that family firms are more likely to offer a higher degree of collateral/commitment protection while introducing competition between banks decreases this likelihood. Trade credit is negatively related to the degree of collateral/commitment protection, indicative of a possible signalling effect of trade credit.

In line with previous studies, we find indications that collateral requirements decrease in the length of the bank-borrower relationship. Furthermore, when a firm introduces more competition between banks for a credit request, it decreases the 
likelihood of having to offer collateral or in case of collateral pledging, to offer personal commitments.

Our results also suggest that beside risk arguments, also commercial arguments determine the pledging of collateral. If a financial institution operates as 'main bank' for a firm, this firm is also more likely to offer collateral/commitments. A theoretical explanation for this behaviour is provided by Mann (1997a, 1997b). Banks often take collateral because secured credit limits the firms ability to obtain future loans from other lenders and reduces the risk of excessive future borrowing. We add to this a more pragmatic explanation. Formalized interviews with the account managers revealed that banks in Belgium usually act in this way because of commercial reasons. Collateral creates a barrier-to-entry for other competing banks if these banks try to capture the client-firm from the main bank.

Lines of credit are more likely to be granted with a higher degree of collateral/commitment protection required than other loans. The provocative 'lazy banks' proposition of Manove et al (2001) is not supported by our results: the pledging of collateral does not seem to be a substitute for the screening efforts of the bank as measured by the time needed to approve the credit request.

Using a continuation-ratio logit model, we discovered several differences in determinants of the collateralisation decision and determinants of the type of collateral/commitments. The signalling effect of trade credit and the amount of the loan are only significant in the type of collateral choice model while the main banker, lines of credit and the maturity of the loan show only significant effects in the collateralisation decision. Generally, our models seem to explain better the collateralisation decision than the type of collateral decision. 
One may question if a banking policy of taking more collateral than necessary from a point of view of risk such as suggested by our results, may lead to the phenomenon of "discouraged borrowers" which has been discussed recently in the academic literature (Levenson and Willard, 2000; Kon and Storey, 2003). Previous research (Binks and Ennew, 1995) indicates that the lenders' demand for personal commitments augments the perceived credit constraints in SMEs. Future research should scrutinize the correlation between banking policy and the phenomenon of discouraged borrowers and demand side-credit rationing. A possible positive relation would shed a different light on the credit rationing debate.

Finally, several issues remain unexplored. We measure collateral protection as an ordinal variable and with dummy variables. Although the majority of current and past empirical studies measure the dependent variable in a similar way, an important dimension of the problem remains unexplored being the amount of collateral/commitments a bank requires. Future research should implement the amount of business collateral and personal commitments as a dependent variable in order to test the robustness of current findings. 


\section{References}

Agresti, A., 2002, Categorical data analysis, Second edition, New-York Wiley.

Ang, J.S., 1992, On the theory of finance for privately held firms, Journal of Small Business Management 1, 185-203.

Ang, J., Lin, J. and Tyler, F., 1995, Evidence on the lack of separation between business and personal risks among small businesses, Journal of Small Business Finance 4, 197-210.

Angelini, P., Di Salvo, R. and Ferri, G., 1998, Availability and cost for small businesses: customer relationships and credit cooperatives, Journal of Banking and Finance 22, 925-954.

Avery, R., Bostic, R. and Samolyk, K., 1998, The role of personal wealth in small business finance, Journal of Banking and Finance 22, 1019-1061.

Berger, A.N. and Udell, G.F., 1995, Relationship lending and lines of credit in small firm finance, Journal of Business 68, 351-381.

Berger, A.N. and Udell, G.F., 2002, Small business credit availability and relationship lending: the importance of bank organisational structure, Economic Journal 112, F32-F53.

Berger, A.N., Klapper, N. and Udell, G.F., 2001, The ability of banks to lend to informationally opaque small businesses, Journal of Banking and Finance 25, $2127-2167$.

Besanko, D. and Thakor, A., 1987a, Collateral and rationing: sorting equilibria in monopolistic and competitive credit markets, International Economic Review 28, 671-689.

Besanko, D. and Thakor, A., 1987b, Competitive equilibrium in the credit market under asymmetric information, Journal of Economic Theory 42, 167-182. 
Bester, H., 1985, Screening vs. rationing in credit markets with imperfect information, American Economic Review 75, 850-855.

Biais, B. and Gollier, C., 1997, Trade credit and credit rationing, Review of Financial Studies 10, 903-938.

Binks, M. and Ennew, C., 1995, The provision of finance to small businesses: does the banking relationship constrain performance?, Journal of Small Business Finance 4, 57-73.

Binks, M. and Ennew, C., 1997, The relationship between UK banks and their small business customers, Small Business Economics 9, 167-178.

Boot, A. and Thakor, A., 1994, Moral hazard and secured lending in an infinitely repeated credit market game, International Economic Review 35, 899-920.

Boot, A., Thakor, A. and Udell G., 1991, Secured lending and default risk: equilibrium analysis, policy implications and empirical results, Economic Journal 101, 458-472.

Bopaiah, C., 1998, Availability of credit to family businesses, Small Business Economics 11, 75-86.

Bruce, N. and Waldman, M., 1990, The rotten kid theorem meets the Samaritan's dilemma, Quarterly Journal of Economics 105, 155-165.

Chan, Y.S. and Kanatas, G., 1985, Asymmetric valuation and the role of collateral in loan agreements, Journal of Money, Credit and Banking 17, 85-95.

Coco, G., 2000, On the use of collateral, Journal of Economic Surveys 14, 191-214.

Cole, R.A., Wolken, J.D. and Woodburn, L.R., 1996, Bank and nonbank competition for small business credit: evidence from the 1987 and 1993 national survey of small business finances, Federal Reserve Bulletin 82, 983-995.

De Meza, D. and Southey, C., 1996, The borrowers curse: optimism, finance and entrepreneurship, Economic Journal 106, 375-386. 
Degryse, H. and Ongena, S., 2005, Distance, lending relationships, and competition, Journal of Finance 60, 231-266.

Degryse, H. and Van Cayseele, P., 2000, Relationship lending within a bank-based system: evidence from European small business data, Journal of Financial Intermediation 9, 90-109.

Deloof, M., 1998, Internal capital markets, bank borrowings, and financing constraints: Evidence from Belgian firms, Journal of Business Finance and Accounting 25, 945-968.

Diamond, D., 1989, Reputation acquisition in debt markets, Journal of Political Economy 97, 828-860.

Diamond, D., 1991, Monitoring and reputation: the choice between bank loans and directly placed debt, Journal of Political Economy 99, 688-721.

Elsas, R. and Krahnen, J.P., 2000, Collateral, default risk and relationship lending: an empirical study on financial contracting, CEPR Discussion paper 2540.

Ferri, G. and Messori, M., 2000, Bank-firm relationships and allocative efficiency in northeastern and central Italy and in the south, Journal of Banking and Finance 24, 1067-1095.

Gertner, R.H., Scharfstein, D.S. and Stein, J.C., 1994, Internal versus external capital markets, Quarterly Journal of Economics 109, 1211-1230.

Greenbaum, S., Kanatas, G. and Venezia, I., 1989, Equilibrium loan pricing under the bank-client relationship, Journal of Banking and Finance 13, 221-235.

Hanley, A., 2002, Do binary collateral outcome variables proxy collateral levels? The case of collateral from start-ups and existing SME's, Small Business Economics 18, 317-331. 
Harhoff, D. and Körting, T., 1998, Lending relationships in Germany - Empirical evidence from survey data, Journal of Banking and Finance 22, 1317-1353.

Jackson, T.H. and Kronman, A.T., 1979, Secured financing and priorities among creditors, The Yale Law Journal 88, 1143-1182.

Jensen, M. and Meckling, W., 1976, Theory of the firm: managerial behavior, agency costs and ownership structure, Journal of Financial Economics 3, 305-360.

Jiménez, G. and Saurina, J., 2004, Collateral, type of lender and relationship banking as determinants of credit risk, Journal of Banking and Finance 28(9), 2191-2212.

Kon, Y. and Storey D.J., 2003, A theory of discouraged borrowers, Small Business Economics 21, 37-49.

Lamont, O., 1997, Cash flow and investment: evidence from internal capital markets, Journal of Finance 52, 83-109.

Leeth, J.D. and Scott, J.A., 1989, The incidence of secured debt: evidence from the small business community, Journal of Financial and Quantitative Analysis 24, 379-394.

Levenson, A.R. and Willard, K.L., 2000, Do firms get the financing they want? Measuring credit rationing experienced by small businesses in the U.S., Small Business Economics 14, 83-94.

Maddala, G.S., 1987, Limited-dependent and qualitative variables in econometrics, (Cambridge University Press New York).

Mann, R.J., 1997a, Explaining the pattern of secured debt, Harvard Law Review 110, 625-683.

Mann, R.J., 1997b, The role of secured credit in small-business lending, The Georgetown Law Journal 86, 1-44. 
Manove, M., Padilla, J. and Pagano, M., 2001, Collateral versus project screening: a model of lazy banks, RAND Journal of Economics 32, 726-744.

Mayer, C., 1988, New issues in corporate finance, European Economic Review 32, 1167-1189.

Morck, R., Shleifer, A. and Vishny, R., 1988, Management ownership and market valuation: an empirical analysis, Journal of Financial Economics 20, 293-316.

Morck, R., and Yeung, B., 2003, Agency problems in large family business groups, Entrepreneurship: Theory \& Practice 27, 367-382.

Myers, S.C., 1977, Determinants of corporate borrowing, Journal of Financial Economics 5, 147-175.

Ongena, S. and Smith, D.C., 2001, The duration of bank relationships, Journal of Financial Economics 61, 449-475.

Petersen, M.A. and Rajan, R.G., 1994, Benefits of lending relationships: evidence from small business data, Journal of Finance 49, 3-37.

Petersen, M.A. and Rajan, R.G., 1995, The effect of credit market competition on lending relationships, Quarterly Journal of Economics 110, 407-443.

Rajan, R, 1992, Insiders and outsiders: the choice between informed and arm's length debt, Journal of Finance 47, 1367-1400.

Rajan, R. and Winton, A., 1995, Covenants and collateral as incentives to monitor, Journal of Finance 47, 1113-1146.

Ramakrishnan, T. and Thakor, A., 1984, Information reliability and a theory of financial intermediation, Review of Economic Studies 51, 415-432.

Scharfstein, D.S. and Stein, J.C., 2000, The dark side of internal capital markets: divisional rent-seeking and inefficient investment, Journal of Finance 55(6), $2537-2564$. 
Schulze, W.S., Lubatkin, M.H. and Dino, R.N., 2003, Exploring the agency consequences of ownership dispersion among the directors of private family firms, Academy of Management Journal 46, 179-194.

Sharpe, S., 1990, Asymmetric information, bank lending, and implicit contract: a sylized model of customer relationships, Journal of Finance 45, 1069-1087.

Shin, H.H. and Stulz, R.M., 1998, Are internal capital markets efficient?, Quarterly Journal of Economics 113, 531-552.

Smith, R.J. and Blundell, R.W., 1986, An exogeneity test for a simultaneous equation tobit model with an application to labor supply, Econometrica 54, 679-686.

Stein, J.C., 1997, Internal capital markets and the competition for corporate resources, Journal of finance 52, 111-133.

Stulz, R.M. and Johnson, H., 1985, An analysis of secured debt, Journal of Financial Economics 14, 501-521.

Wilner, B.S., 2000, The exploration of relationships in financial distress: the case of trade credit, Journal of Finance 55, 153-178. 
Table 1

Sample Statistics

\begin{tabular}{lrrrr}
\multicolumn{1}{c}{ Variable } & Mean & Std Dev & Min & Max \\
\hline \hline TA (total assets) & $3,885.37$ & $7,487.67$ & 57.00 & $52,975.00$ \\
TRADECR (acc. pay./TA) & 0.288 & 0.186 & 0.00 & 0.79 \\
$\begin{array}{l}\text { RELATION (with the bank in } \\
\text { years) }\end{array}$ & 11.53 & 8.66 & 0.00 & 50.00 \\
$\begin{array}{l}\text { COMPETITION (number of } \\
\text { other competing banks) }\end{array}$ & 0.62 & 0.87 & 0.00 & 4.00 \\
$\begin{array}{l}\text { MATURITY (time to } \\
\text { maturity in months) }\end{array}$ & 36.99 & 33.98 & 0.00 & 180.00 \\
$\begin{array}{l}\text { AMOUNT (of loan in } € \text { ) } \\
\text { JUDGE_TIME (No. of days }\end{array}$ & 289,326 & 789,201 & 6,256 & $7,100,000$ \\
needed to make a credit & 12.7 & 17.9 & 0.00 & 161.00 \\
decision) & & & & \\
AGE (of the firm in months) & 164.56 & 116.66 & 12.00 & 663.00 \\
\hline \hline
\end{tabular}

Sample size $=234$ observations

${ }^{1}$ In thousands

Table 2

Percent distributions of firms in the sample

\begin{tabular}{|c|c|}
\hline Variable & Percent distribution \\
\hline \multicolumn{2}{|l|}{ Main bank } \\
\hline 'Main bank' & $91.5 \%$ \\
\hline Other bank & $8.5 \%$ \\
\hline \multicolumn{2}{|c|}{ Collateral Protection (dependent variable) } \\
\hline No Collateral Protection & $12.39 \%$ \\
\hline Business Collateral & $57.26 \%$ \\
\hline Personal Commitments & $30.34 \%$ \\
\hline \multicolumn{2}{|l|}{ Relation } \\
\hline No relation & $2.56 \%$ \\
\hline $1-2$ years & $7.26 \%$ \\
\hline $3-5$ years & $23.50 \%$ \\
\hline $6-10$ years & $16.67 \%$ \\
\hline $11-25$ years & $41.03 \%$ \\
\hline$>25$ years & $8.97 \%$ \\
\hline \multicolumn{2}{|c|}{$\begin{array}{l}\text { Number of other competing banks contacted for a } \\
\text { credit request }\end{array}$} \\
\hline No other banks involved & $55.6 \%$ \\
\hline 1 other bank & $32.1 \%$ \\
\hline$>1$ other bank & $12.3 \%$ \\
\hline \multicolumn{2}{|l|}{ Loan size } \\
\hline$<€ 100,000$ & $53.0 \%$ \\
\hline$€ 100,000-€ 500,000$ & $36.3 \%$ \\
\hline$>€ 500,000$ & $10.7 \%$ \\
\hline \multicolumn{2}{|l|}{ Year of credit approval } \\
\hline 2000 & $4.7 \%$ \\
\hline 2001 & $29.9 \%$ \\
\hline 2002 & $58.1 \%$ \\
\hline 2003 & $7.3 \%$ \\
\hline Lines of credit & $18.8 \%$ \\
\hline Family firms & $81 \%$ \\
\hline Affiliated firms & $14 \%$ \\
\hline
\end{tabular}

Sample size $=234$ observations 
Table 3

Ordered probit estimation of the determinants of collateral/commitment protection

\begin{tabular}{|c|c|c|c|}
\hline Variable & $(1)$ & (2) & (3) \\
\hline \multicolumn{4}{|l|}{ Firm characteristics } \\
\hline FAMILY & $\begin{array}{l}1.574 * * * \\
(0.277)\end{array}$ & $\begin{array}{l}1.581 * * * \\
(0.278)\end{array}$ & $\begin{array}{c}1.553^{* * *} \\
(0.273)\end{array}$ \\
\hline TRADECR & $\begin{array}{c}-1.513 * * * \\
(0.456)\end{array}$ & $\begin{array}{c}-1.537 * * * \\
(0.461)\end{array}$ & \\
\hline MOTHDAU*TRADECR & & & $\begin{array}{c}-1.423 * * * \\
(0.441)\end{array}$ \\
\hline $\begin{array}{l}(1-\text { MOTHDAU }) * \\
\text { TRADECR }\end{array}$ & & & $\begin{array}{c}-2.954 * * * \\
(1.138)\end{array}$ \\
\hline \multicolumn{4}{|l|}{ Relationship characteristics } \\
\hline $\ln (1+$ RELAT $)$ & $\begin{array}{c}0.199 \\
(0.132)\end{array}$ & $\begin{array}{c}0.153 \\
(0.133)\end{array}$ & $\begin{array}{c}0.214 \\
(0.135)\end{array}$ \\
\hline MAIN_BANK & $\begin{array}{c}1.706 * * * \\
(0.415)\end{array}$ & $\begin{array}{l}1.761 * * * \\
(0.420)\end{array}$ & $\begin{array}{c}1.669 * * * \\
(0.421)\end{array}$ \\
\hline COMPETITION & $\begin{array}{l}-0.354 * * * \\
(0.094)\end{array}$ & & $\begin{array}{c}-0.347 * * * \\
(0.095)\end{array}$ \\
\hline One other bank ${ }^{1}$ & & $\begin{array}{l}-0.225 \\
(0.185)\end{array}$ & \\
\hline$>1$ other bank & & $\begin{array}{c}-0.893 * * * \\
(0.282)\end{array}$ & \\
\hline \multicolumn{4}{|l|}{ Loan characteristics } \\
\hline $\mathrm{L} / \mathrm{C}^{2}$ & $\begin{array}{l}0.484 * \\
(0.259)\end{array}$ & $\begin{array}{l}0.487 * \\
(0.260)\end{array}$ & $\begin{array}{c}0.505^{*} \\
(0.258)\end{array}$ \\
\hline MATURITY & $\begin{array}{l}0.005^{*} \\
(0.003)\end{array}$ & $\begin{array}{l}0.005^{*} \\
(0.002)\end{array}$ & $\begin{array}{l}0.005^{*} \\
(0.003)\end{array}$ \\
\hline $\ln (\mathrm{AMOUNT})$ & $\begin{array}{l}-0.088 \\
(0.069)\end{array}$ & $\begin{array}{l}-0.084 \\
(0.070)\end{array}$ & $\begin{array}{l}-0.076 \\
(0.069)\end{array}$ \\
\hline \multicolumn{4}{|l|}{ Lender characteristics } \\
\hline JUDGE_TIME & $\begin{array}{c}0.002 \\
(0.004)\end{array}$ & $\begin{array}{c}0.001 \\
(0.004)\end{array}$ & $\begin{array}{c}0.002 \\
(0.005)\end{array}$ \\
\hline \multicolumn{4}{|l|}{ Control variables } \\
\hline $\ln (\mathrm{TA})$ & $\begin{array}{c}0.301 * * * \\
(0.087)\end{array}$ & $\begin{array}{c}0.282 * * * \\
(0.085)\end{array}$ & $\begin{array}{c}0.292 * * * \\
(0.087)\end{array}$ \\
\hline $\ln (\mathrm{AGE})$ & $\begin{array}{l}-0.125 \\
(0.147)\end{array}$ & $\begin{array}{l}-0.083 \\
(0.147)\end{array}$ & $\begin{array}{l}-0.137 \\
(0.144)\end{array}$ \\
\hline MOTHDAU & $\begin{array}{c}0.096 \\
(0.280)\end{array}$ & $\begin{array}{c}0.074 \\
(0.285)\end{array}$ & \\
\hline No. of obs. & 234 & 234 & 234 \\
\hline$\chi^{2}$ & $94.37 * * *$ & $85.59 * * *$ & $91.50 * * *$ \\
\hline Pseudo-R ${ }^{2}$ & 0.231 & 0.229 & 0.237 \\
\hline
\end{tabular}

$* * * *, * * *$ significant at the $10 \%, 5 \%$ and $1 \%$ level respectively (two-tailed test). Robust asymptotic standard errors reported in parentheses. The dependent variable consists of three categories ranging from 'no protection' to 'highest protection': (1) unsecured debt, (2) secured debt with only business collateral and (3) secured debt with personal commitments. Each regression includes 3 year dummies.

1 "No other banks involved" during the credit request is the suppressed comparison category.

2 This variable is a recoding of the variable MATURITY. By putting both variables in the model, the model can also be written in the form: (1-OTHER_LOAN) x L/C and OTHER_LOAN x MATURITY with OTHER_LOAN as a dummy variable coded " 0 " if the loan is a line of credit and " 1 " otherwise. 
Table 4

Continuation-ratio logit estimation of the determinants of collateral/commitment protection.

\begin{tabular}{|c|c|c|c|c|}
\hline \multirow[t]{2}{*}{ Variable } & \multicolumn{2}{|c|}{ (1) } & \multicolumn{2}{|c|}{$(2)$} \\
\hline & $\begin{array}{c}\ln \left(\mathrm{P}_{\mathrm{no}} / \mathrm{P}_{\text {bus }}+\right. \\
\left.\mathrm{P}_{\text {per }}\right) \\
\end{array}$ & $\ln \left(\mathrm{P}_{\text {bus }} / \mathrm{P}_{\text {per }}\right)$ & $\ln \left(\mathrm{P}_{\mathrm{no}} / \mathrm{P}_{\mathrm{bus}}+\mathrm{P}_{\mathrm{per}}\right)$ & $\ln \left(\mathrm{P}_{\text {bus }} / \mathrm{P}_{\text {per }}\right)$ \\
\hline \multicolumn{5}{|l|}{ Firm characteristics } \\
\hline FAMILY & $\begin{array}{c}-4.75 * * * \\
(1.050)\end{array}$ & $\begin{array}{c}-2.860 * * \\
(1.224)\end{array}$ & $\begin{array}{c}-5.26 * * * \\
(1.169)\end{array}$ & $\begin{array}{c}-2.893 * * \\
(1.260)\end{array}$ \\
\hline TRADECR & $\begin{array}{c}1.320 \\
(2.083)\end{array}$ & $\begin{array}{l}3.31 * * * \\
(1.130)\end{array}$ & $\begin{array}{c}1.500 \\
(2.369)\end{array}$ & $\begin{array}{c}3.272 * * * \\
(1.150)\end{array}$ \\
\hline \multicolumn{5}{|c|}{ Relationship characteristics } \\
\hline $\ln (1+$ RELAT $)$ & $\begin{array}{c}0.815 \\
(0.498)\end{array}$ & $\begin{array}{l}-0.546 \\
(0.374)\end{array}$ & $\begin{array}{l}1.003^{*} \\
(0.541)\end{array}$ & $\begin{array}{l}-0.529 \\
(0.366)\end{array}$ \\
\hline MAIN_BANK & $\begin{array}{c}-6.06 * * * \\
(1.201)\end{array}$ & $\begin{array}{l}-0.389 \\
(1.097)\end{array}$ & $\begin{array}{c}-6.79 * * * \\
(1.593)\end{array}$ & $\begin{array}{l}-0.467 \\
(1.087)\end{array}$ \\
\hline COMPETITION & $\begin{array}{l}1.499 * * \\
(0.682)\end{array}$ & $\begin{array}{c}0.820 * * \\
(0.338)\end{array}$ & & \\
\hline One other bank ${ }^{1}$ & & & $\begin{array}{c}1.051 \\
(1.368)\end{array}$ & $\begin{array}{l}0.679 * \\
(0.401)\end{array}$ \\
\hline$>1$ other bank & & & $\begin{array}{c}4.792 * * * \\
(1.700)\end{array}$ & $\begin{array}{c}2.141 \\
(1.344)\end{array}$ \\
\hline \multicolumn{5}{|l|}{ Loan characteristics } \\
\hline $\mathrm{L} / \mathrm{C}^{2}$ & $\begin{array}{l}-2.436^{*} \\
(1.253)\end{array}$ & $\begin{array}{l}-0.682 \\
(0.607)\end{array}$ & $\begin{array}{l}-2.464 * \\
(1.428)\end{array}$ & $\begin{array}{l}-0.690 \\
(0.609)\end{array}$ \\
\hline MATURITY & $\begin{array}{l}-0.078^{*} \\
(0.044)\end{array}$ & $\begin{array}{c}0.007 \\
(0.006)\end{array}$ & $\begin{array}{l}-0.077^{*} \\
(0.049)\end{array}$ & $\begin{array}{c}0.007 \\
(0.006)\end{array}$ \\
\hline $\ln (\mathrm{AMOUNT})$ & $\begin{array}{l}-0.068 \\
(0.296)\end{array}$ & $\begin{array}{l}0.291^{*} \\
(0.170)\end{array}$ & $\begin{array}{l}-0.080 \\
(0.250)\end{array}$ & $\begin{array}{l}0.284^{*} \\
(0.169)\end{array}$ \\
\hline \multicolumn{5}{|c|}{ Lender characteristics } \\
\hline JUDGE_TIME & $\begin{array}{c}0.025 \\
(0.022)\end{array}$ & $\begin{array}{c}0.007 \\
(0.017)\end{array}$ & $\begin{array}{c}0.034 \\
(0.021)\end{array}$ & $\begin{array}{c}0.009 \\
(0.017)\end{array}$ \\
\hline \multicolumn{5}{|l|}{ Control variables } \\
\hline $\ln (\mathrm{TA})$ & $\begin{array}{c}-1.31 * * * \\
(0.425)\end{array}$ & $\begin{array}{l}-0.376^{*} \\
(0.221)\end{array}$ & $\begin{array}{c}-1.42 * * * \\
(0.443)\end{array}$ & $\begin{array}{l}-0.362^{*} \\
(0.219)\end{array}$ \\
\hline $\ln (\mathrm{AGE})$ & $\begin{array}{c}-2.68 * * * \\
(0.609)\end{array}$ & $\begin{array}{l}1.18 * * * \\
(0.339)\end{array}$ & $\begin{array}{c}-3.07 * * * \\
(0.622)\end{array}$ & $\begin{array}{c}1.146 * * * \\
(0.340)\end{array}$ \\
\hline MOTHDAU & $\begin{array}{c}0.448 \\
(1.151)\end{array}$ & $\begin{array}{l}-0.723 \\
(0.775)\end{array}$ & $\begin{array}{c}0.813 \\
(1.147)\end{array}$ & $\begin{array}{l}-0.636 \\
(0.839)\end{array}$ \\
\hline No. of obs. & 234 & 205 & 234 & 205 \\
\hline $\begin{array}{l}\chi^{2} \\
\text { Pseudo-R }{ }^{2}\end{array}$ & 0.654 & 0.242 & 0.668 & 0.242 \\
\hline
\end{tabular}

**,**,*** significant at the $10 \%, 5 \%$ and $1 \%$ level respectively (two-tailed test). Robust asymptotic standard errors reported in parentheses. The dependent variable consists of two dummies: (1) $\ln$ $\left(\mathrm{P}_{\text {no }} /\left(\mathrm{P}_{\text {bus }}+\mathrm{P}_{\text {per }}\right)\right)$ is the choice between no collateral $(=1)$ and collateral/commitments $(=0)$, $(2) \ln$ $\left(\mathrm{P}_{\text {bus }} / \mathrm{P}_{\text {per }}\right)$ is the choice between business collateral $(=1)$ and personal collateral/commitments $(=0)$. Each regression includes 3 year dummies.

1 "No other banks involved" during the credit request is the suppressed comparison category.

2 This variable is a recoding of the variable MATURITY. By putting both variables in the model, the model can also be written in the form: (1-OTHER LOAN) $x$ L/C and OTHER LOAN x MATURITY with OTHER_LOAN as a dummy variable coded " 0 " if the loan is a line of credit and " 1 " otherwise. 